\title{
SOBRE A REPÚBLICA NOS TEMPOS DO IMPÉRIO: ENTRE A HISTÓRIA E A TEORIA SOCIAL
}

\section{David Francisco Lopes Gomes ${ }^{1}$}

\section{Resumo}

Este artigo aborda a história dos conceitos de república e de soberania no século XIX brasileiro. O objetivo é demonstrar que a compreensão do conceito de república não é possível sem a compreensão de suas relações internas com o conceito de soberania, mas, ao mesmo tempo, essa compreensão demanda um pano de fundo que só pode ser oferecido por uma reflexão advinda da teoria social. Em primeiro lugar, discute-se o conceito de república entre 1750 e 1850, tal qual apresentado pelo projeto Iberconceptos. Em seguida, foca-se nos escritos de Frei Caneca para analisar mais especificamente o conceito de república no contexto da Independência do Brasil e para relacioná-lo ao conceito de soberania. Logo após, demonstra-se a articulação em geral entre os conceitos de república e de soberania da Independência do Brasil até o Manifesto do Partido Republicano. Finalmente, apresenta-se uma reflexão sobre a relação entre história e teoria social.

Palavras-chave: República; Soberania; Século XIX Brasileiro; Teoria Social.

\section{INTRODUÇÃO}

Gostaria de começar este texto com três citações:

A coroação de d. Pedro constituiu o desfecho desse drama, transformando-o em um soberano com amplos poderes, que detinha, além do poder executivo, a partilha da soberania nacional com os representantes da Nação. Vencera a postura mais moderada da elite coimbrã, com a instalação de um Estado cuja concepção não se afastava tanto das práticas do absolutismo ilustrado. (NEVES, 2003, p. 411)

Nessas condições, a política limitava-se à disputa de ingressos para esses círculos privados em que se tomavam as decisões, restando aos excluídos do momento o manejo da retórica liberal, sob a forma de invectivas contra o despotismo ministerial e a influência dos áulicos cujas reiterações passariam a constituir uma das constantes da história brasileira - seja com o objetivo, mais frequente de candidatar-se às posições privilegiadas, seja, mais raramente, como a manifestação impotente de autênticos anseios por uma política verdadeiramente pública. (NEVES, 2003, p. 418, destaques da autora)

Como resultado dessas contradições, o Império do Brasil não brotou das inspirações liberais que o período da Independência colocou em circulação, mas nasceu e foi acalentado, mais propriamente, sob o signo do mesmo absolutismo ilustrado que forjara a ideia de império para conservar o que supunha sempre haver sido. (NEVES, 2003, p. 418)

\footnotetext{
1 Doutorando em Direito pela UFMG. Professor assistente do Departamento de Direito da UFLA. E-mail: david.gomes@dir.ufla.br
} 
Esses três trechos pertencem a uma das mais importantes obras das últimas décadas sobre a Independência do Brasil. Defendido como tese de doutorado em 1992 e publicado como livro em 2003, o texto de Lúcia Maria Bastos Pereira das Neves integra o profundo processo de renovação da história política que tem tido lugar no Brasil, a partir da exploração de novas fontes e do manuseio de novas concepções teóricas e metodológicas. $^{2}$

Em que pese a ampla base sobre a qual se apoia, constituída sobretudo pela análise dos panfletos e periódicos da época da Independência, e conquanto seja inegável o valor historiográfico que sua crítica dessas fontes primárias possui, Lúcia das Neves acaba chegando a conclusões como as que estão consubstanciadas nas citações acima: a Independência brasileira sendo marcada, no fim das contas, pelo predomínio da soberania do monarca; a política, então inaugurada, definida por círculos privados, rara e impotentemente enfrentados em prol de uma vivência "política verdadeiramente pública"; o resultado do processo como sendo a construção de algo que se forja para preservar, por meio de uma suposta mudança, o que se supunha ter sido, e poder continuar sendo, sempre o mesmo.

A "mão poderosa" do imperante, a política restrita e manchada por interesses privados, a história que é sempre mais do mesmo: esses caracteres ocupam não apenas o imaginário brasileiro relativo à Independência, mas o imaginário brasileiro relativo à história do Brasil como um todo. ${ }^{3}$ É esse imaginário que parece atuar como pano de fundo das conclusões de Lúcia das Neves, um pano de fundo não problematizado e não problematizável, isto é, um pano de fundo que informa como que de fora o caminho que as análises deverão seguir até aquelas conclusões, sem poder ser ele mesmo colocado em xeque pelas análises que guia.

Como consequência, as conclusões a que Lúcia das Neves chega entram em contradição com o corpo dos seus argumentos: afinal, não se trata de um equívoco intencional ou subjetivo da autora, mas de uma contradição objetiva entre as fontes - por ela analisadas criteriosamente - e um imaginário que antecede a própria análise. Assim, mesmo após descrever a efervescência de uma nascente esfera pública no início do século XIX brasileiro, caracterizada inclusive pela participação de setores não alfabetizados e pela preocupação pedagógica de se ampliarem os limites da política (NEVES, 2003, p. 107-113), Lúcia das Neves não conclui senão com a imagem amorfa de uma política sem tensões, homogeneamente restrita e excludente; mesmo depois de ter

\footnotetext{
${ }^{2}$ Essa renovação é constatada, dentre outros, por CARVALHO, 2009 e PALTI, 2009. São inúmeros os trabalhos que poderiam ser elencados dentro dessa onda renovadora. Em relação ao século XIX, merecem destaque: ARAÚJO, 2008; CARVALHO, 2007; CARVALHO; NEVES, 2009; DANTAS, 2011; GRINBERG; SALLES, 2009; JANCSÓ, 2003; JANCSÓ, 2005; LUSTOSA, 2000; LUSTOSA, 2004; MALERBA, 2006; MOREL, 2005; PEREIRA, 2010. Para uma perspectiva historiográfica mais geral, cf. CANCELLI, 2009.

${ }^{3}$ No horizonte da renovação historiográfica mencionada na nota anterior, muitos dos trabalhos têm procurado romper com esse imaginário. Nesse sentido, gostaria de destacar MOREL, 2005 e PEREIRA, 2010. Além desses dois textos - frutos de teses de doutoramento -, vários capítulos também possuem uma tônica parecida nas seguintes coletâneas: CARVALHO, 2007; CARVALHO; NEVES, 2009; GRINBERG; SALLES, 2009; JANCSÓ, 2003; JANCSÓ, 2005; MALERBA, 2006.
} 
mostrado exemplarmente os meandros em torno do problema da soberania que atravessarão a política brasileira já em 1822 (NEVES, 2003, p. 159-162; 375-411), Lúcia das Neves mantém-se atada à imagem de um imperador soberano, não muito distante nem distinto das concepções e das práticas absolutistas ilustradas.

Tendo em vista a elevada qualidade do texto elaborado por Lúcia das Neves, é no mínimo razoável afirmar que essas contradições objetivas não se fariam nele presentes se o imaginário do qual derivam não estivesse arraigado tão profundamente, e com tamanha força, no ambiente acadêmico, no ambiente político e no ambiente social brasileiro em geral. Para permanecermos restritos ao ambiente acadêmico, basta citar a tradição teórica conhecida como "intérpretes do Brasil": o que escorre das páginas magistralmente escritas por alguns dos nomes mais importantes da intelectualidade brasileira não é, muitas vezes, mais do que um fel ressentido por um país que não foi, por um povo que teria estado ausente da escrita de sua história ${ }^{4}$, por uma política que jamais teria estado livre da corrupção ${ }^{5}$, por uma república inacabada ${ }^{6}$, por uma democracia impossível ${ }^{7}$, enfim.

Frente a esse imaginário e ao resseguro acadêmico que ele carrega consigo, fica clara a relevância de se perguntar novamente pela história da nossa república. Ou melhor, pela história da república entre nós. Neste pequeno texto, tento mostrar que essa história começa bem antes de 1889. Para tanto, começo retomando a história do conceito de república entre 1750 e 1850, na linha do projeto Iberconceptos ${ }^{8}$. Em seguida, aprofundo a análise do contexto da Independência do Brasil, com ênfase nos escritos de Frei Caneca. São esses textos de Frei Caneca que me conduzem ao terceiro passo de minha argumentação. Em tal passo, extrapolo os limites do próprio conceito de república para buscar seu sentido prático em sua articulação com outros conceitos políticos fundamentais: mais especificamente, com o conceito de soberania. É com a articulação entre esses dois conceitos república e soberania - que chego ao movimento republicanista das últimas décadas do império brasileiro. Finalmente, desloco-me do plano da análise dos conceitos para o plano de uma reflexão teórica mais elementar, com a qual procuro mostrar que - não obstante a imprescindibilidade de reflexões de ordem filosófica e

\footnotetext{
${ }^{4}$ Cf. BONAVIDES; ANDRADE, 2008.

${ }^{5}$ Para o lugar que a corrupção costuma ocupar nessa tradição teórica e para uma análise crítica desse lugar, cf. SOUZA, 2009; SOUZA 2012.

${ }^{6}$ Cf. COMPARATO, 2007.

${ }^{7}$ FERREIRA FILHO, 1979. Para uma análise crítica, cf. GOMES, 2010 e CATTONI DE OLIVEIRA, 201 lb.

${ }^{8}$ No site do projeto, é possível encontrar esta descrição: "O Projeto Iberoamericano de História Conceitual, mais conhecido como IBEROCONCEPTOS, tem como principal objetivo estudar de maneira sistemática, a longo prazo e numa perspectiva comparada, os mais importantes conceitos, linguagens, vocabulários, discursos e metáforas políticas que circularam no mundo iberoamericano nos últimos séculos. Nosso trabalho concentra-se especialmente na fase de transição para a modernidade, a qual se estende das últimas décadas do século XVIII avançando bastante pelo século XIX, período que, não por acaso, coincide com a fase crucial das revoluções liberais e de independência." (IBERCONCEPTOS, 2015). Assim, o projeto debruça-se sobre a história conceitual nos seguintes países: Argentina, Brasil, Chile, Colômbia, Espanha, México, Peru, Portugal e Venezuela. Os resultados dos estudos desenvolvidos estão disponibilizados no Diccionario Político y Social del Mundo Ibero-Americano, publicado em 2 tomos, em um total de 11 volumes, sob a coordenação de Javier Fernández Sebastián (SEBASTIÁN, 2009; 2014). Em relação ao Brasil, os primeiros resultados do projeto, contidos em seu primeiro tomo, podem ser também consultados em FERES JÚNIOR, 2009a. Ali, antes dos verbetes, há uma introdução sobre o Iberconceptos, com ênfase em sua base metodológica: FERES JÚNIOR, 2009 b.
} 
metodológica internamente à historiografia ${ }^{9}$ - uma compreensão adequada da história não pode ser alcançada sem uma teoria social que a sustente. Para os três primeiros passos, valho-me das ferramentas fornecidas pelo Enfoque Collingwoodiano ${ }^{10}$ e pela História dos Conceitos, tal qual desenvolvida por Reinhart Koselleck. Para o quarto e último passo, trago à cena a teoria social crítica desenvolvida em torno do Instituto de Frankfurt.

\section{O CONCEITO DE REPÚBLICA ENTRE 1750-1850}

Segundo Christian Lynch e Heloisa Starling, a história do conceito de república entre 1750 e 1850 pode ser "sincronicamente dividida em quatro grandes fases" (LYNCH; STARLING, 2009, p. 226). A primeira delas iria da metade até o final do século XVIII, mais especificamente de 1750 a 1792 :

o conceito esteve principalmente associado à tradição clássica que remontava a Políbio e Cícero, que ao traduzir do grego o termo politeía de Aristóteles como res publica, legara ao mundo latino o duplo sentido do conceito. Mais amplo, o primeiro concebia a constituição da comunidade voltada para o bem comum; ao passo que o segundo, mais restrito, exprimia o de governo gerido por magistrados extraídos da camada popular. (LYNCH; STARLING, 2009, p. 226)

Esse segundo sentido relacionava-se, em termos práticos, à autonomia administrativa local, que se materializava nas câmaras municipais e que tinha como seus agentes os "homens bons da terra", isto é, pessoas que fossem naturais da colônia, dotadas de um grau mínimo de "civilidade" e possuidoras de bens. É essa acepção, cujo melhor exemplo vinha de Veneza, na Itália mediterrânea, que estará na base do enfrentamento entre pretensões autonomistas dos colonos e posturas restritivas da metrópole, atuando como motor ideológico de movimentos como a Guerra dos Mascates, em 1710, e a Inconfidência Mineira, em 1789 (LYNCH; STARLING, 2009, p. 226-227).

Nesse mesmo ano de 1789, eclodia a Revolução Francesa. Seus ecos nas Américas marcarão uma segunda fase do conceito de república, agora entendida como sinônimo de democracia: "é apenas depois de 1792 que se fixa no Brasil um sentido de república claramente para além daquele consagrado pela tradição clássica aquele sinônimo de democracia." (LYNCH; STARLING, 2009, p. 229, destaque dos autores).

Associada às então chamadas "abomináveis ideias francesas", essa nova camada de sentido que se depositava no termo seria uma das responsáveis, no mundo colonial luso, pela resistência ímpar que o conceito de

\footnotetext{
${ }^{9} \mathrm{O}$ século XX foi extremamente rico nesse sentido. Dentre as muitas obras que se propuseram a uma reflexão filosófica e/ou metodológica no âmbito próprio da ciência histórica, podem-se destacar: LE GOFF, 1993; KOSELLECK, 2006; KOSELLECK; GADAMER, 1997; POCOCK, 2003; RICOEUR, 2000. Para além de P. Ricoeur e sua pretensão de, como ele mesmo a chama, uma filosofia crítica da história, as outras obras oferecem uma boa amostragem de três das mais importantes discussões de ordem filosófica e/ou metodológica no campo da história ao longo do século passado: os Annales, com J. Le Goff; a História dos Conceitos, com R. Koselleck; e o Enfoque Collingwoodiano, com J. Pocock.

${ }^{10}$ Também conhecido como Contextualismo de Cambridge ou simplesmente Escola de Cambrigde. Cf. FERES JÚNIOR, JASMIM, 2006, p. 11.
} 
república enfrentaria em sua fase seguinte, ou seja, no processo de emancipação política do Brasil em face de Portugal:

O terceiro momento do conceito data de 1821 , isto é, da chegada das notícias da Revolução Constitucionalista do Porto e da proclamação da liberdade de imprensa. (...) o significado que então prevaleceu foi aquele que o fazia sinônimo de democracia ou de governo popular efetivo. (LYNCH; STARLING, 2009, p. 231, destaque dos autores)

Em relação a esse terceiro momento, porém, a afirmação de Christian Lynch e de Heloisa Starling, conforme a qual teria prevalecido a concepção do termo como sinônimo de democracia ou de governo popular efetivo, requer alguns esclarecimentos.

Desde a chegada, na colônia, das notícias da Revolução do Porto, o Brasil passou a viver um período até ali inédito de efervescência política. Em momentos como esse, a quantidade, a qualidade, a densidade e o ritmo das mudanças expressam-se inevitavelmente no plano conceitual. Assim, tanto palavras velhas ganham novos sentidos como palavras novas surgem - os neologismos. De igual modo, a rapidez das mudanças ocasiona uma aceleração no tempo tal como percebido na vivência cotidiana, dando origem a palavras também elas temporalizadas, isto é, marcadas em sua própria estrutura pelo reflexo do tempo acelerado, o que em geral consubstancia-se no acoplamento a essas palavras de um sufixo apto a transmitir a ideia de movimento - no caso do Brasil, o sufixo -ismo (KOSELLECK, 2006, p. 297; NEVES, 2003, p. 115-226). Além disso, essa aceleração das mudanças e da correspondente percepção do tempo torna a base de referência das palavras no mundo algo sem solidez, muito mais situada na abstração das expectativas futuras do que na concretude do presente, o que permite que tais palavras se refiram a muitas coisas ao mesmo tempo, inclusive a alguma coisa e a seu exato contrário, dando margem a um intenso processo de crítica ideológica (KOSELLECK, 2006, p. 301-303).

Tudo isso será verificado no Brasil do começo da terceira década do século XIX, valendo, portanto, também para o conceito de república. Por conseguinte, a primeira questão a ser destacada é o fato de que, em geral, rótulos como república, republicanismo e republicano não eram assumidos voluntariamente como traço identitário de pessoas, grupos ou posturas políticas, sendo, antes, atribuídos por adversários para caracterizarem uns aos outros, não a si mesmos. A isso, acresça-se que a acusação de republicanismo era uma das imputações da moda no debate político daquela época (CANECA, 2001d, p. 136). Raramente se assumia como republicano, mas frequentemente se acusava outrem de sê-lo.

Uma segunda questão importante passa pela lembrança de que aquilo a que essa acusação poderia referir-se no mundo prático variava enormemente, podendo relacionar-se a outros conceitos como federalismo, feudalismo e inclusive despotismo:

bispos sem papa, a que eu também chamarei os incompreensíveis. Estes que não querem ser monárquico-constitucionais, que não podem ser corcundas e que não querem ser republicanos de uma só república, querem um governo monstruoso; um centro de poder nominal, e cada província uma pequena república, para serem nelas chefes absolutos, 
corcundas despóticos. (ANDRADA E SILVA, 2002,p. 174)
Nesse sentido, Christian Lynch e Heloisa Starling concluem: "Desse modo, federalismo se tornava
feudalismo, e república, despotismo" (LYNCH; STARLING, 2009, p. 233, destaques dos autores).
Uma terceira questão que não pode deixar de ser abordada diz respeito a que, embora o horror à república, exacerbado pelo isolamento de uma monarquia cercada pelas repúblicas recém-emancipadas da Espanha, tenha feito prevalecer o sentido de república como sinônimo da então temível e odiável democracia ${ }^{11}$, suas outras camadas de sentido não estiveram ausentes do cenário político da Independência, como veremos no próximo tópico ao tratarmos mais especificamente dos textos de Frei Caneca.

Conquanto proclamada a Independência, outorgada a Constituição de 1824 e massacrada a Confederação do Equador, as discussões em torno do conceito de república não cessariam por completo, e o apogeu de seu prestígio político seria a reforma constitucional de 1834 (LYNCH; STARLING, 2009, p. 239). Ao mesmo tempo, porém, as decorrências daquela reforma marcariam a passagem para a quarta e última fase da história do conceito de república entre 1750 e 1850:

O quarto momento do conceito no Brasil começou justamente, então, quando ficou claro que, ao invés de reduzir as ameaças de separatismo, o experimento descentralizador e democratizante da reforma constitucional as havia antes fomentado, aprofundando a desordem, e que o caminho para a paz estava na fórmula inversa - reforçar o poder do governo central e prestigiar o elemento monárquico. (LYNCH; STARLING, 2009, p. 239)

Dentre os argumentos que eram levantados para justificar o abandono dos ideais republicanos e federalistas ${ }^{12}$, destacam-se dois: a suposta falta de civismo do povo brasileiro e a associação da república ao ímpeto da mocidade, a uma opção irrefletida típica da juventude e que cedia naturalmente espaço à defesa da monarquia constitucional na medida em que os anos passavam e a maturidade chegava. Quanto ao primeiro desses argumentos, a permanência do regime escravocrata faria uma república no Brasil soar como algo caricato, dada a ausência das virtudes cívicas sem as quais nenhuma república era possível. Quanto ao segundo argumento, é com base nele que alguém como Antônio Carlos de Andrada Machado justificava sua trajetória política e a mudança de postura entre o jovem revolucionário republicano de Pernambuco em 1817 e o moderado defensor da monarquia constitucional já nos finais da década de 1830 (LYNCH; STARLING, 2009, p. 239-240).

\footnotetext{
${ }^{11}$ É importante lembrar que essa aversão à democracia nos séculos XVIII e XIX não era privilégio do Brasil. Nos famosos Federalist Papers, textos escritos em prol da ratificação da Constituição dos Estados Unidos durante o processo de discussão e votação da mesma pelos então Estados confederados, a defesa da república é feita, muitas vezes, em conjunto com a crítica da democracia entendida como seu oposto. Cf. HAMILTON; MADISON; JAY, 1961.

${ }^{12}$ Em geral, a interpretação do ideal republicano no Brasil do século XIX é feita destacando-se a dependência desse ideal em relação às pretensões autonomistas das localidades distintas do Rio de Janeiro. Assim, nessa interpretação, a república costuma, não poucas vezes, permanecer à sombra do federalismo. Neste texto, afasto-me, ainda que apenas parcialmente, de tal interpretação. Como mostrarei mais abaixo, sem dúvida as pretensões autonomistas jogaram um papel de extrema importância na política brasileira do
} 


\section{FREI CANECA, A REPÚBLICA E A SOBERANIA}

Inelutavelmente, falar sobre o conceito de república no século XIX brasileiro implica falar de Pernambuco:

Tanto pela persistência do ideal republicano clássico da aristocracia rural como pela simpatia de alguns setores urbanos da capital, Recife, pelo discurso igualitário jacobino, a tradição republicana encontraria seu reduto por excelência durante a primeira metade do século XIX, na província de Pernambuco. (LYNCH; STARLING, 2009, p. 230)

E falar de república em Pernambuco no século XIX não é possível sem se referir a Frei Joaquim do Amor Divino Caneca, ou simplesmente Frei Caneca. As circunstâncias históricas específicas em que ele viveu e escreveu fazem de sua obra um lugar privilegiado para compreender-se o debate em torno do conceito de república e o sentido prático desse debate em um momento crucial da história do país, isto é, no momento mesmo em que se definia o que seria o país então nascente.

Uma primeira observação importante pode ser mais bem compreendida se se tem em mente uma preocupação característica de J. Pocock ${ }^{13}$ : "estabelecer o pertencimento de um determinado conceito a linguagens políticas de seu tempo" (FERES JÚNIOR, 2009b, p. 13). Dentro dessa lógica, buscar as tradições de pensamento que estavam na base dos escritos de Frei Caneca e cujas linguagens específicas apareciam imiscuídas nesses escritos contribui para o esclarecimento dos sentidos que os conceitos utilizados em tais textos assumiam.

Uma das tradições de pensamento que mais nitidamente se destaca na obra de Caneca é o republicanismo clássico. Logo, aquele duplo sentido do conceito, legado ao mundo latino pela tradução da politeía aristotélica como res publica, atravessará toda essa obra. Por um lado, república podia significar um governo conduzido pelos "homens bons da terra"; por outro lado, todavia, podia significar simplesmente uma organização social voltada para o bem comum.

Essa ambiguidade do conceito possibilitava, por exemplo, que Frei Caneca, em discurso no qual celebrava concomitantemente a conceição de Nossa Senhora e a aclamação de Pedro como imperador, escrevesse o seguinte:

Enlaçando entre si os sentimentos, que hoje nos devem animar quanto à religião e à política, na piedade cristã e na república civil, nossos corações se devem inundar da mais afluente alegria e do mais completo júbilo, pelo grande interesse que reina nos dois objetos da presente solenidade: a Conceição intemerata da imperatriz do céu e da terra, e a aclamação do imperador constitucional do Brasil. (CANECA, 2001b, p. 106)

Ou seja, era perfeitamente possível elogiar, a um só tempo, a república civil e o imperador constitucional.

século XIX. Mas mesmo elas não fariam sentido sem uma articulação mais complexa entre o ideal republicano e a concepção correspondente de soberania.

${ }^{13}$ Cf. POCOCK, 2003, particularmente, p. 63-82. 
Nessa acepção, o conceito de república aproximava-se do conceito de pátria. Não a pátria natural, o lugar de nascimento, mas a pátria já redefinida por Caneca como preferencial, a pátria de direito, na qual se é aceito como cidadão e a qual se escolhe para habitação e para a formação de estabelecimentos econômicos (CANECA, 2001a, p. 70; 75-84):

De tudo isso se conhece que não há coisa alguma no cidadão que se não deva propor ao bem da pátria; e tudo se deve sacrificar à conservação, lustre e glória da república.

Talentos, pensamentos, palavras, obras, tudo é da república.

Riquezas, propriedades, honras, lugares, em tudo tem um direito inalienável a pátria. (CANECA, 2001a, p. 95)

Se a república e o imperador constitucional podiam ser elogiados conjuntamente, outra observação relevante refere-se ao que se entendia por império constitucional:

O império constitucional ou é uma concepção de uma inteligência acima da dos mortais ou é uma dessas verdades sublimes com que nos costuma presentear o acaso, ou, se nasceu da reflexão, é a obra prima da razão, e o maior esforço do entendimento humano no artigo política.

Império constitucional?

Colocado entre a monarquia e o governo democrático, reúne em si as vantagens de uma e de outra forma, e repulsa para longe os males de ambas. Agrilhoa o despotismo, e estanca os furores do povo indiscreto e volúvel. (CANECA, 2001b, p. 117) ${ }^{14}$

Império constitucional exprimia, dessa maneira, o equilíbrio almejado para a organização da sociedade política, opondo-se aos abusos e às arbitrariedades de um ou de muitos, alcançando com isso a preservação do bem comum.

Diante de um império concebido a partir dessa leitura, Frei Caneca recusava expressamente a acusação de republicanismo no sentido mais restrito do termo república, a saber, no sentido que a compreendia como um governo conduzido por "homens bons da terra" extraídos da população em geral e, por consequência, oposto à monarquia:

Como, porém, fosse necessário ter um ponto de apoio, em que equilibrasse a sua incendiária máquina, lança mão da imputação da moda, de quererem os que não são Gama e seus aderentes estabelecer uma república em Pernambuco.

(...)

Dize, malvado, se nós quiséssemos república, quem nos impediria de fazer?

(...)

Se em 1817 fomos tão arrojados que não tememos todo o Brasil e todo Portugal reunidos, e proclamamos uma república, como agora o deixaríamos de fazer por medo de menos de um terço desse inimigo de outrora? (CANECA, 2001d, p. 136-137)

Se a razão para não se proclamar uma república não adivinha do medo, ela precisava ser encontrada em outra ordem de motivações. Novamente, adentrava a cena discursiva o conceito de império constitucional:

Sabes, portanto, que não proclamamos uma república porque não queremos; e não queremos, não por temor de nada, sim porque esperamos ser felizes em um império

\footnotetext{
${ }^{14}$ Sobre a aversão à democracia nos séculos XVIII e XIX, cf. nota 10 acima.
} 
constitucional; (...). (CANECA, 2001d, p. 140)

Isso poderia levar à conclusão de que a defesa da república nos anos do processo da Independência não passava, como regra, da postura política de vintistas extremados, "que somente premidos ao último limite rompiam com a fórmula de transigência da monarquia constitucional" (LYNCH; STARLING, 2009, p. 236237). Esta é a opinião de Christian Lynch e Heloísa Starling: "Como conceito autônomo, portanto, a república era bastante débil" (LYNCH; STARLING, 2009, p. 238).

Uma tal leitura, contudo, parece inadequada, posto que não considera uma dimensão fundamental dos textos que se apresentam em alguma medida como discursos políticos. Trata-se daquela dimensão à qual $\mathrm{Q}$. Skinner ${ }^{15}$ dedicou maior atenção, perguntando-se pelo quê os autores estavam fazendo com os textos que escreviam. Em outras palavras, qual era o sentido prático desses textos, a quem se dirigiam, com quem dialogavam, quais efeitos esperavam produzir?

Se tomarmos o parágrafo completo da última passagem de Frei Caneca citada acima, essa dimensão começa a ficar clara:

Sabes, portanto, que não proclamamos uma república porque não queremos; e não queremos, não por temor de nada, sim porque esperamos ser felizes em um império constitucional; porquanto, no caso oposto, sucederá entre Pernambuco e o sul o mesmo que s.m.i.c. disse a seu pai na carta de 22 de setembro do ano passado que sucederia entre o Brasil e Portugal, isto é, que Pernambuco será escravizado, mas os pernambucanos não. (CANECA, 2001d, p. 140)

Ao lado da aceitação do império constitucional, e como elemento constitutivo dessa aceitação, figurava a ameaça da ruptura. Essa mesma estratégia argumentativa repetia-se em várias outras passagens, de diversos outros escritos de Caneca. O que fica claro em todas elas é que, na fórmula do império constitucional, o que importava mais era o adjetivo "constitucional" e menos o substantivo "império", isto é, que o império constitucional era reconhecido e elogiado não por ser império, mas por ser constitucional, e, tão logo deixasse de ser constitucional, estava justificada a resistência a ele e também o rompimento com ele.

Retornando ao discurso proferido para celebrar a aclamação de Pedro como imperador, pode-se ler:

O imperador, podendo fazer todo o bem a seus súditos, jamais causará mal algum, porque a Constituição com sábias leis fundamentais e cautelas prudentes tira ao imperador o meio de afrouxar a brida às suas paixões e exercitar a arbitrariedade. (CANECA, 2001b, p. 117)

O clímax dessa estratégia argumentativa consistia em trazer à colação palavras do próprio Pedro nas quais ele supostamente sustentaria o mesmo ponto de vista defendido por Caneca, qual seja, o de que acima dele, como poder pessoal, estava a constituição, como ata do pacto social (CANECA, 2001f, p. 459; 473):

Ali s.m. prometeu, de modo mais positivo, que o Congresso soberano, representativo do generoso povo brasileiro, era quem havia de fazer a Constituição do império. Leia-se este monumento da sabedoria, da constitucionalidade de um príncipe que se sacrificou todo pelos brasileiros (...). (CANECA, 2001f, p. 341)

\footnotetext{
${ }^{15}$ Cf. SKINNER, 1985; SKINNER, 1986; SKINNER, 2002. Mais especificamente, SKINNER, 1985, p. 11.
} 
Em outro texto:

Em todos os papéis que correm impressos, quer sejam feitos por s.m.i.c., quer dirigidos a ele pelos povos e seus representantes, ou se vê às escâncaras, ou se dá a entender, que a Constituição do império há de ser feita pelo soberano Congresso, representante da nação, e não pelo imperador. (CANECA, 2001e, p. 202)

O fato de a Assembleia Constituinte haver sido dissolvida pelo imperador não obstaculizava o uso da estratégia, exigindo tão somente uma reconfiguração dos argumentos apta a atribuir a responsabilidade pelos atos arbitrários a outros atores políticos:

Amanheceu nesta corte o lutuoso dia 12 de novembro, dia nefasto para a liberdade do Brasil e sua independência; dia em que se viu com o maior espanto representada a cena do 18 de Brumaire ( 8 de novembro), em que o déspota da Europa dissolveu a representação nacional da França; dia em que o partido dos chumbeiros do Rio de Janeiro pôs em prática as tramóias do ministério português, e conseguiu, iludindo a cândida sinceridade de s.m.i. dissolver a suprema Assembleia Constituinte Legislativa do Império do Brasil. (CANECA, 2001f, p. 304)

Essa última passagem encontra-se no número I de O Typhis Pernambucano ${ }^{16}$, datado de 25 de dezembro de 1823. Duas semanas depois, no número III do mesmo periódico, logo no início vem estampado:

Depois de se ter demonstrado nos números antecedentes a falsidade do motivo que a perversa facção portuguesa teve a habilidade de empregar para iludir e violentar a s.m.i. a acabar com a soberana Assembleia Constituinte brasiliense, arriscando desta feição a integridade do império com a desconfiança e a insurreição das províncias, e abrindo ao Brasil os abismos da anarquia e guerra civil (...). (CANECA, 2001f, p. 319)

Uma vez outorgada a Constituição de 1824 por Pedro, a estratégia precisava novamente de uma reconfiguração. Aquele elogio pretérito ao imperador dava lugar a certo enfrentamento e a uma cobrança mais direta, o que fica claro, por exemplo, no número XXV de O Typhis Pernambucano, publicado em 8 de julho de 1824, isto é, o primeiro número depois de proclamada a Confederação do Equador no dia 2 de julho daquele ano:

Como tem s.m. desempenhado o título de defensor perpétuo do Brasil, título em que s.m. pôs toda a sua glória? Oh desgraça! A primeira ocasião que se oferece de cumprir com esse dever, torce s.m., foge a defesa e nos deixa em desamparo, entregues unicamente a nossos recursos: quem tal pensara!

(...)

Que traição! Que perfídia!

E ainda dirá s.m. que é nosso defensor perpétuo?

Defensores desta qualidade são defensores? (CANECA, 2001f, p. 505)

De toda sorte, a estratégia argumentativa será reconfigurada, mas não simplesmente abandonada.

Capturado e interrogado, Caneca escreve em suas memórias sobre o ocorrido:

Fui arguido de ter escrito no meu Typhis contra o imperador etc.; ao que respondi negando toda a acusação; 1o.) porque nos meus Typhis somente a doutrina, que constantemente se achava era advogar a sagrada causa do império brasileiro, por dever de bom filho, amante da pátria; 2o.) porque nesse tempo havia liberdade de imprensa, mesmo por decreto de s.m.i.; 3o.) porque s.m. o imperador mesmo tinha ordenado em uma proclamação sua que advogássemos a causa do Brasil, ainda mesmo que fosse contra a sua pessoa. (CANECA,

\footnotetext{
${ }^{16}$ Trata-se do periódico fundado, redigido e publicado semanalmente por Frei Caneca entre dezembro de 1823 e agosto de 1824.
} 
2001i, p. 604)

Finalmente, na defesa formal apresentada à comissão militar pela qual foi processado e condenado, lê-se:

Que a soberania reside na nação, que a nação é quem se constitui e por meio dos seus representantes em Cortes - dois pontos cardeais em que rola toda a doutrina do Typhis são duas verdades confessadas por s.m. no decreto de 8 junho de 1822, no manifesto de 6 de agosto do mesmo ano aos povos e nações amigas, além de outras ocasiões. (CANECA, 2001j, p. 629)

Se a estratégia argumentativa consistia em acatar o império constitucional dando mais relevância ao adjetivo "constitucional" do que ao substantivo "império" - ou seja, colocando-se a constituição acima do império e, principalmente, da figura pessoal do imperador - e se o clímax dessa estratégia era alcançado no momento em que se valia de declarações do próprio imperador nesse mesmo sentido, há algo, então, que parece não fazer sentido: por que depois da outorga da Constituição de 1824, depois, portanto, que o império tinha finalmente uma constituição e era, pois, o almejado império constitucional, os ânimos não só continuaram acirrados, como houve inclusive um recrudescimento das tensões, culminando na Confederação do Equador? Por que Confederarão do Equador se já havia constituição? Por que escritos contra o império e também já diretamente contra o imperador se este havia dado àquele a desejada constituição?

A resposta predominante a essas perguntas toma como chave explicativa as pretensões autonomistas locais, que viram suas expectativas federalistas definitivamente frustradas frente ao Estado unitário e excessivamente centralizado estabelecido pela Constituição de 1824.

Sem dúvida, o elemento federalista jogou um papel fundamental no desenrolar da trama. Mas essa trama não pode ser entendida sem um outro fio interpretativo, que já se faz presente em algumas das passagens transcritas acima: trata-se do tema da soberania ${ }^{17}$. Com a fórmula do império constitucional, pretendia-se outra coisa que a simples organização de uma monarquia por meio de uma constituição. Pretendia-se, antes de tudo, um império cuja constituição fosse elaborada pelos representantes da nação, não pelo próprio imperador. Pretendiase, por conseguinte, uma monarquia despida de seus elementos clássicos, esvaziada de seu eixo fundamental, posto que a soberania não poderia ser entendida como derivando da hereditariedade do sangue ou do desígnio de Deus, mas somente da vontade dos povos. Pretendia-se, em suma, uma monarquia republicanizada, cuja tradução se dava nos termos de uma soberania nacional ou popular ${ }^{18}$.

Já em suas Cartas de Pítia a Damão, redigidas em 1823, Caneca escreve:

\footnotetext{
${ }^{17}$ Dadas as opções metodológicas do presente artigo, não é possível proceder a uma definição prévia do conceito de soberania assim como não foi feito quanto ao conceito de república - para, só então, procurar demonstrar como teria ocorrido a apropriação desse conceito ao longo da história. Ao contrário, é da própria história de seus usos e da superposição de suas camadas semânticas que emerge algo como "um conceito de soberania". Não obstante, é possível afirmar que o campo referencial a que esse conceito alude - campo referencial que é exatamente aquilo que permite dizer tratar-se, apesar de suas variações, de um único conceito relaciona-se diretamente ao problema da legitimidade para o exercício do poder político.

${ }^{18}$ A distinção entre soberania popular e soberania nacional não faz sentido no âmbito dos textos de Frei Caneca. Abaixo, abordo essa distinção, relevante para a compreensão do debate geral em torno da soberania no século XIX.
} 
Portanto, meu caro Damão, faze um serviço à humanidade e dá glória a Deus, abrindo os olhos a esse pobre povo, em que vives. Dize-lhes que a soberania não vem imediatamente de Deus, e sim dos mesmos povos, como até confessa o mesmo imperador, no seu decreto de 3 de junho do ano passado; (...). (CANECA, 2001e, p. 184)

Mas é em O Typhis Pernambucano que a questão assume um tom mais definitivo. Em suplemento ao número XI do periódico, publicado no dia 15 de março de 1824, Caneca afirma:

O poder soberano, isto é, aquele que não reconhece outro acima de si, existe na nação. (...).

(...)

(...) residindo a soberania na nação, como até s.m.i.c. tem por muitas vezes confessado à face do universo, e sendo unicamente a nação a que se deve constituir, só ela usa de um direito seu inauferível na escolha das matérias que sejam o objeto do pacto social, ou imediatamente, ou pela mediação de seus legítimos representantes em cortes, ou, se tem cometido a alguém a esboçar o projeto da sua Constituição, este sempre deve ser discutido e aprovado em cortes constituintes, pois só aí é que há representação nacional. (CANECA, 2001f, p. 393-394).

No número XXII, de 17 de junho do mesmo ano, vem descrita a decisão tomada pelo conselho que havia se reunido para deliberar acerca da ordem dada pelo decreto imperial de 11 de março de 1824, no qual se mandava jurar o projeto de constituição elaborado por Pedro e por seu Conselho de Estado:

Celebrou-se o conselho, e se decidiu por totalidade de votos, que se não desse à execução o mencionado decreto de 11 de março deste ano porque o projeto, além de ser uma carta imperial, na qual se estabelecia o mais detestável despotismo, que esta cidade havia jurado repulsar com todas as forças, viesse ele de onde viesse, era oferecido por quem não tinha autoridade para o dar, portanto sendo uma atribuição essencial da soberania da nação a escolha e arranjo da matéria do pacto social, era esta escolhida e apresentada pelo imperador, que, sendo criatura da nação, não tem soberania, e deve portanto receber da nação a Constituição que esta lhe der (....). (CANECA, 2001f, p. 473, destaques do autor)

$\mathrm{O}$ conceito de soberania percorre um bom número das páginas de Frei Caneca ${ }^{19}$. E, também no que diz respeito ao elemento federalista - às pretensões autonomistas locais -, ele só adquire seu sentido e justificativa plenos à luz da concepção de soberania expressa por Caneca:

O Brasil, só pelo fato de sua separação de Portugal e proclamação da sua independência, ficou de fato independente, não só no todo como em cada uma de suas partes ou províncias; e estas, independentes umas das outras.

Ficou o Brasil soberano, não só no todo, como em cada uma das suas partes ou províncias.

(...)

No meio dessas possibilidades, o Rio, pelo poder soberano que tinha no seu território, aclamou s.m. imperador constitucional, e então s.m. não ficou mais do que imperador do Rio de Janeiro. As outras províncias, ou seduzidas pelos emissários do Rio, ou por seu mesmo conhecimento, esperando que nesta forma de governo podiam achar a felicidade a que aspiravam, foram-se chegando muito de sua vontade aos negócios do Rio, aclamando a s.m. imperador constitucional, com o que nada mais fizeram que declarar que se uniam todas para formar um império constitucional, e que s.m. seria o seu imperador.

Daqui se conhece que duas são as condições da união das províncias com o Rio de Janeiro, a

\footnotetext{
${ }^{19}$ Sem pretensão exaustiva: CANECA 2001d, p. 138; 2001e, p. 183, 184, 185, 191, 197, 203, 204, 205, 206, 210, 248, 297; $2001 \mathrm{f}$, p. 304, 307-308, 311, 312, 314, 315, 319, 321, 331, 334, 335, 337, 338, 345, 353, 363, 367, 382, 393-395, 417-418, 434, 441, 443, 445, $446,452,454,455,458-459,463-465,473,484,503,508-509,518-519 ; 2001$ g, p. 542; 2001h, p. 560, 563-564, 565, 566; 2001 j, p. $613,629,632,635$.
} 
saber, que se estatua império constitucional, e que s.m. seja o imperador; de modo que, se o Rio de Janeiro quiser coisas fora ou contrárias a qualquer destas duas condições, está desfeita a união, que mal se achava esboçada, e cada província libérrima para, pelo seu poder soberano no seu território, proclamar e estatuir aquela forma de governo que bem quiser, como fez o Rio proclamando império constitucional.

(...)

Já se deixa ver que os efeitos da falta do cumprimento dessas duas condições são os mesmos, se acaso o imperador for o que as embarace, contra o voto das províncias, como desgraçadamente sucedeu com a dissolução despótica e à força de armas da soberana Assembleia.

(...)

Pelo que, está dissolvida a prometida e não consumada união das províncias; e, por esta razão, cada uma reintegrada na sua independência e soberania. (CANECA, 2001f, p. 463465).

Se é verdade que a ênfase do programa da Confederação do Equador era mais a federação do que a república ${ }^{20}$, a própria possibilidade da federação requeria o argumento de uma soberania nacional ou popular - de uma soberania republicana ${ }^{21}$.

Como conclusão, se a história de um conceito não se confunde com a história de uma palavra, se a história de um conceito somente pode ser compreendida se se analisam tanto as distintas ordens de coisas no mundo a que se refere uma mesma palavra quanto as distintas palavras que se referem a uma mesma ordem de coisas no mundo (KOSELLECK, 2006, p. 105), então a história do conceito de república - que é o tema do qual aqui me ocupo - no Brasil do século XIX não pode ser adequadamente entendida senão em conjunto com a história do conceito de soberania. Transcendendo o plano meramente conceitual, isso significa que a história da luta pela república no Brasil não pode ser entendida sem a história das disputas em torno da soberania.

Assim, retornando a Q. Skinner, pode-se perceber que o que Frei Caneca fazia com seus textos não era transigir com o império, com a monarquia constitucional, e revelar a debilidade do conceito autônomo de república no século XIX brasileiro, como pretendem Christian Lynch e Heloisa Starling (LYNCH; STARLING, 2009, p. 236-237). Não se tratava de aceitar o império no lugar da república. Mas, ao contrário, de deixar claro que só se aceitaria o império como república. E que, se não fosse assim, a resistência armada e a ruptura seriam a alternativa.

\section{A SOBERANIA, DA ACLAMAÇÃO DE PEDRO AO MANIFESTO DO PARTIDO REPUBLICANO}

Ainda que a argumentação do tópico precedente esteja correta, se ela fosse válida apenas para Frei Caneca, ou para o âmbito restrito de Pernambuco e adjacências, a conclusão de Christian Lynch e Heloisa

\footnotetext{
${ }^{20}$ MELLO, 2001, p. 39.

${ }^{21}$ Cf. nota 11 acima.
} 
Starling acerca da debilidade da república como conceito autônomo não estaria refutada: Caneca, Pernambuco e região poderiam ser a célebre exceção que confirma a regra.

Entretanto, uma articulação semelhante entre república e soberania - articulação que, como vimos mostrando, reposiciona o problema da história do conceito de república no século XIX brasileiro - pode ser verificada na cena política do nascente país como um todo. No Rio de Janeiro, por exemplo, isso fica claro em episódios como aqueles referentes ao juramento prévio da constituição portuguesa a ser elaborada pelas Cortes de Lisboa, à reunião da Praça do Comércio, ao juramento das bases daquela que viria a ser a constituição portuguesa e ao Conselho de Procuradores.

Se todos esses episódios se situam antes da declaração de Independência, declarada esta as tensões ganhariam força. Afinal, o que passava a estar em jogo era o fundamento da política e do direito no novo país, isto é, o fundamento da legitimidade do poder e da autoridade das leis no Estado que acabara de surgir como tal no mundo.

Já imediatamente após a proclamação da Independência, por exemplo, as simbologias em torno da aclamação e da coroação do imperador dariam vazão ao confronto entre acepções distintas de soberania. Em cada uma das cerimônias, detalhes como os passos seguidos na ritualística, as pessoas presentes na celebração, o arranjo das posições dos indivíduos que se faziam presentes, o caminho percorrido pelo imperador, a ordem das falas: tudo isso (NEVES, 2003, p. 375-411) revelava, na diferença entre uma cerimônia e outra, a disputa em torno da soberania que tinha lugar naquele momento.

Enquanto a aclamação havia sido organizada pelo grupo liderado principalmente por Gonçalves Ledo e José Clemente Pereira, a coroação havia sido obra sobretudo do grupo liderado por José Bonifácio de Andrada e Silva. Os primeiros, muitas vezes acusados de republicanismo, eram adeptos de uma soberania popular; o segundo opunha-se a ela. Por conseguinte, toda a dimensão simbólica por detrás da aclamação, celebrada no dia 12 de outubro, parecia querer dizer que Pedro somente era imperador por vontade do povo e que, por causa disso, acima dele e antes dele estava a soberania situada na nação. O ponto alto dessa posição política era alcançado quando José Clemente Pereira, presidente do Senado da Câmara do Rio de Janeiro, discursando antes de Pedro, apresentava as razões pelas quais o Brasil se havia separado de Portugal e afirmava a origem popular do título ostentado pelo imperador (NEVES, 2003, p. 382).

Não por acaso, logo depois da aclamação, uma reviravolta política, cuja cumeada foi uma devassa extremamente arbitrária que passou à história com o nome de Bonifácia (LUSTOSA, 2004, p. 63), fez com que o grupo de Ledo e José Clemente fosse afastado de modo praticamente definitivo do cenário político do recémnascido império. Estava aberto o caminho para que o grupo de Bonifácio organizasse uma nova cerimônia: a coroação, a ser celebrada no dia 01 de dezembro. 
Nessa nova cerimônia, o aspecto restrito e o tom sacro que a cercava procuravam dizer o contrário do que havia sido expresso em 12 de outubro: a soberania não residia no povo ou na nação, mas no monarca, por desígnio de Deus. A culminação dessa nova cerimônia e de seu sentido prático seria um discurso proferido por Pedro ao final de todo o ritual. Dos balcões do Paço, espada em punho, Pedro terminaria dizendo que jurava defender o império do Brasil e a constituição liberal digna dele e do país. Inspirado em Luís XVIII, tratava-se de uma espécie de antecipação da fala com a qual o aclamado e coroado imperador abriria os trabalhos da Assembleia Constituinte no dia 3 maio de 1823 (NEVES, 2003, p. 409).

O que fica nítido nas distinções entre essas cerimônias e, principalmente, na aclamação e no desfecho trágico que os responsáveis por ela tiveram na política, é que Ledo e José Clemente não estavam simplesmente transigindo com a monarquia, com a fórmula do império constitucional, por debilidade da república como um conceito autônomo na política imperial. Uma vez mais, o que acontecia era uma tentativa, levada ao limite, de defesa da república, de defesa de um império que só podia ser aceito como república ${ }^{22}$.É isso inclusive que ajuda a explicar a violência a que se recorreu contra aquele grupo logo em seguida. Se as circunstâncias não permitiram que a palavra república se fizesse presente, ou fizeram com que ela fosse expressamente recusada, isso não significa que sua semântica própria, que as camadas de sentido que compõem, não a palavra, mas o conceito de república, estiveram ausentes. Também aqui, esse conceito só revela sua história quando esta vem unida à história do conceito de soberania e às disputas em torno desse conceito.

Essas disputas seguiriam seu turno e chegariam ao seu apogeu na Assembleia Constituinte. Desde antes de sua abertura, ainda durante as sessões preparatórias, a soberania já se mostrava o tema axial da Assembleia (LUSTOSA, 2004, p. 51-79): como se vestiria o imperador ao vir à Assembleia? Com ou sem as insígnias imperiais? Viria ou não acompanhado de seus ministros? Estando presente, seu assento seria superior ou não ao assento do presidente da Assembleia? E este deveria ou não oferecer uma resposta em seguida à fala com a qual o imperador abriria os trabalhos da Assembleia? (BRASIL, 1973, p. 1-13).

Chegava o dia 3 de maio e, em sua fala de abertura, Pedro retomava as palavras que havia proferido no dia de sua coroação: defenderia a pátria, defenderia a nação e defenderia a Constituição, se fosse digna do Brasil e

\footnotetext{
${ }^{22}$ Certamente, essa complexa teia de argumentação e prática política não prescinde de uma base material que lhe agregue sentido. Dentro dessa lógica, os interesses na manutenção do escravismo foram fundamentais para a união de grupos políticos distintos em torno do imperador. É essa a interpretação de Menelick de Carvalho Netto (1992), apoiado em Ilmar Rohloff de Mattos (2004). Todavia, essa interpretação não exclui o fato de que, quando os elementos republicanos desses grupos, movidos por interesses materiais, aproximaram-se do imperador, essa aproximação ocorreu exatamente do modo como procuro sustentar, isto é, como a aceitação de uma monarquia apenas na medida em que ela é despida de seus elementos típicos, como a aceitação de uma monarquia republicanizada. Sem dúvida, isso aponta para os limites do ideal republicano no Brasil do século XIX, deixando claro que a almejada república, para boa parte de seus adeptos, não deveria significar abolição da escravatura. Mas nada se altera em relação à argumentação que vem sendo desenvolvida neste texto: no limite, quando a recusa expressa da monarquia não se fazia uma opção viável, a estratégia política consistia em defender uma monarquia republicanizada, uma monarquia moldada na forma de uma república, ainda que na forma de uma república extremamente excludente.
} 
dele (BRASIL, 1973, p. 15-19). Era o necessário para que as sessões seguintes da Assembleia fossem fortemente marcadas pela disputa em torno da soberania: poderia o monarca recusar a constituição a ser elaborada pela Assembleia? A quem caberia decidir se essa constituição era ou não digna do Brasil e dele? Quem estava acima de quem? Quem era o soberano de quem?

No calor da discussão, uma fala de Andrada Machado e Silva seria bastante reveladora, sobremaneira em suas entrelinhas. Afirmava ele que povo e nação eram palavras diferentes, que não podiam ser confundidas, sob pena de desordem. A nação abrangia o "Soberano e os Subditos", enquanto o povo compunha-se apenas dos "Subditos". O "Soberano" era a "razão social, collecção das razões individuais". O povo era o "Corpo que obedece á razão". A confusão entre as duas palavras, conduzindo à "almagação imphilosophica da Soberania e povo", gerava consequências que "ensanguentarão a Europa, e nos ameação tãobem". Nesse sentido, Andrada Machado e Silva solicitava que se substituísse povo por nação sempre que se falasse de soberania (BRASIL, 1973, p. 31).

Com essa fala, somada aos outros acontecimentos e discursos até aqui trabalhados, é possível perceber que pelo menos três posições principais acerca da soberania concorriam entre si na política brasileira de então. Em um extremo do espectro, estavam os que entendiam que a soberania residia no próprio monarca. No outro extremo, os que entendiam que a soberania se situava no povo. No meio do caminho, os que distinguiam entre povo e nação, entendendo que a soberania era um atributo da nação, mas que esta, por sua vez, era composta pelo povo, como totalidade de súditos, e pelo monarca. Para estes, embora a soberania fosse algo uno e indivisível, o seu exercício deveria ser compartilhado entre o imperador e os representantes do povo reunidos em Assembleia. ${ }^{23}$

O alerta de Andrada Machado e Silva, segundo o qual a junção entre soberania e povo, que havia causado tantos males à Europa, também ameaçava o Brasil, dá provas da força relativa de que o argumento da soberania popular gozava naquele contexto. Certamente, pode-se pensar que há certa dose de exagero e retórica em sua fala, e pode-se perguntar o que também ele estava fazendo com aquelas palavras, o que ele exatamente fazia ao falar, na busca por hegemonia dentro da Assembleia e na defesa de uma posição política específica. Mas, ainda assim, e por isso mesmo, o exagero e a retórica, construídos em volta das alegadas ameaças representadas por uma concepção popular de soberania, somente fazem sentido se se parte precisamente da força relativa que tal concepção de fato já possuía. Do contrário, a retórica não passaria de retórica vazia; e o exagero, de simples paranoia, contradizendo-se com sua própria finalidade de servir de ferramenta para a competição política.

Diante de tudo isso, o meu argumento principal sobre a história do conceito de soberania no século XIX brasileiro - precipuamente a partir de fins de 1820, quando as notícias da Revolução do Porto chegam ao Brasil - é o seguinte: todo esse período será atravessado por uma tensão constante entre as variadas concepções de soberania que circulavam à época, das quais aquelas três resumidas acima, como modelos discursivos ideais, são as 
mais destacadas. Essa tensão constante, essa disputa acerca da soberania, não se resolverá ao longo de toda a história do império. Haverá, sem dúvida, momentos mais curtos ou mais longos de relativa estabilização dessas tensões, prevalecendo uma ou outra concepção de soberania que, dadas as circunstâncias específicas de cada um desses momentos, conseguia sobrepor-se às outras. Mas essa prevalência jamais significará exclusividade ou definição da disputa, durando apenas até que novas circunstâncias venham outra vez alterar o equilíbrio de forças e reavivar as tensões que estiveram por algum tempo latentes. Ou seja, não houve, em todo esse período histórico, uma "mão mais poderosa" (GOMES, 2015). A permanência dessa tensão, por sua vez, revela, ao mesmo tempo, a permanência ativa do ideal republicano.

Entre maio e novembro de 1823, a Assembleia Constituinte e as relações dela com o imperador seriam o principal foco das tensões em torno da soberania. Em 12 de novembro, essas tensões culminariam na dissolução da Assembleia pelo imperador. Se esse ato poderia parecer apontar para o predomínio absoluto da soberania monárquica, para a efetivação máxima do monarca como soberano, o decreto de dissolução e outras proclamações imperiais que se seguiram a ele mostram bem que tal predomínio não era possível nos quadros dos debates e práticas políticas daqueles anos ${ }^{24}$. Em tais documentos, Pedro precisa buscar justificativas para o seu ato acusado de arbitrário, e a justificativa principal é a promessa de uma nova Assembleia Constituinte e de uma Constituição ainda mais liberal do que aquela que vinha sendo elaborada pela Assembleia dissolvida. Um monarca soberano, que precisa justificar seus atos nesses termos, já coloca em questão, no próprio ato de se justificar, a sua condição de soberano, escancarando com isso o fato de que sua alegada soberania não estava assentada em bases sólidas, mas permanecia em xeque.

Outorgada a Constituição de 1824, poucos meses depois eclodiria a Confederação do Equador, com todo o seu fundamento, conforme visto no tópico anterior, no problema da soberania. No texto da Constituição, por outro lado, vinha escrito em seu artigo 11: "Os Representantes da Nação Brazileira são o Imperador, e a Assembléa Geral" (BRASIL, 2015), dando-se a entender que aquela concepção de soberania situada no meio do caminho era a que prevalecia e estabilizava de algum modo as tensões em jogo.

Bastou ter início a primeira legislatura para que as forças políticas se reconfigurassem e aquela estabilização mostrasse toda sua fragilidade. Institucionalmente, a tônica era dada pelo enfrentamento entre a Assembleia e o imperador. Para além das barreiras institucionais, das ruas vinham também elementos de peso para a continuação das contendas: a população passava a recorrer cada vez mais ao poder legislativo por meio de petições, nas quais em geral ele aparece nomeado como "Soberano Congresso" (PEREIRA, 2010).

\footnotetext{
${ }^{23}$ Cf. nota 17 acima.

${ }^{24}$ Cf. DECRETO, 2008a, p. 557; DECRETO, 2008b, p. 559; MANIFESTO, 2002, p. 558; PROCLAMAÇÃO, 2002, p. $741-742$.
} 
Sete anos depois da outorga da Constituição de 1824, o desgaste da relação entre Pedro e o legislativo seria um dos motivos que levariam a sua abdicação. Em seguida, conforme apontado por Christian Lynch e Heloisa Starling (LYNCH; STARLING, 2009, p. 239), o período regencial e a reforma constitucional de 1834 representariam uma espécie de apogeu para o prestígio político do conceito de república. Logo, também ali, seja na reforma, no regresso conservador ou na reação liberal a esse regresso, as tensões em torno da soberania manifestar-se-iam com todas as suas cores.

O golpe da maioridade e o início do reinado de Pedro II, porém, não sepultariam o debate, não encerrariam as disputas, sendo apenas mais um daqueles momentos de relativa estabilização das tensões. Retornando à Constituição de 1824, se ela, por um lado, havia dividido a representação da Nação entre o imperador e o poder legislativo, por outro lado havia trazido, logo em seu preâmbulo, a afirmação de que Pedro era imperador constitucional e defensor perpétuo do Brasil por graça de Deus e unânime aclamação dos povos. Essa dupla fonte alegada de legitimidade, somando-se à previsão da figura do poder moderador nos artigos 10 e 98 a 101 (BRASIL, 2015), poderia significar que na verdade o monarca permanecia como soberano, posto que, na dualidade de sua legitimação - por Deus e pelo povo - e de seu lugar institucional - como poder executivo e como poder moderador -, ele se situava ao mesmo tempo dentro da relação entre os poderes e acima de todos eles.

Essa linha de interpretação, contudo, desconsidera que a simples previsão constitucional da figura do poder moderador não conseguia definir de antemão seu sentido, seu fundamento e os limites e possibilidades de sua prática: a busca dessa definição, que já se fazia objeto de disputa no primeiro reinado, será uma das principais ocasiões para a continuidade dos enfrentamentos entre acepções distintas do conceito de soberania ao longo do segundo reinado, como se percebe a partir do debate entre Braz Florentino Henriques de Souza e Zacharias de Go囚ez e Vasconcellos ${ }^{25}$. O que esse debate permite vislumbrar é que, para além da suposta indistinção entre liberais e conservadores, concepções distintas acerca do fundamento da política e do direito, acerca da legitimidade do poder e da autoridade das leis, continuavam colocando políticos diferentes em campos opostos.

Esse breve resgate histórico apresentado não é mais do que um panorama do que foram aquelas décadas. Entretanto, quanto mais se aprofunda nos detalhes da política imperial brasileira, mais seus meandros dão prova da plausibilidade da argumentação aqui desenvolvida.

Todavia, a maior prova dessa plausibilidade - a maior prova de que, ao longo do século XIX brasileiro, acepções diversas do conceito de soberania permaneceram em tensão constante, sem que nenhuma tenha definitivamente se sobreposto às outras, e que a república e a soberania não se compreendem nesse século senão conjuntamente interpretadas - é o Manifesto do Partido Republicano, de 1870: "Na ${ }^{\circ}$ o reconhecendo nós outra 
soberania mais do que a soberania do povo para ella appellamos. Nenhum outro tribunal póde julgar-nos: nenhuma outra auctoridade pode interpo^r-se entre ella e nós" (MANIFESTO, 1998, p. 243).

Mais do que voltar a abordar expressamente a ideia de uma soberania que se situa exclusivamente no povo, o que o manifesto expressa é, uma vez mais e como nunca havia deixado de ser, a relação interna entre soberania popular e república. No corpo do manifesto, ficaria clara também a relação entre ambos esses conceitos e a defesa do federalismo. ${ }^{26}$

\section{DA HISTÓRIA A TEORIA SOCIAL}

Entre 1870 e 1889, conferências, atos, discursos, debates na imprensa, arranjos e rearranjos políticos seriam levados a cabo pelos republicanos, com idas e vindas, voltas e reviravoltas. Apesar de toda essa atuação, proclamada a república ela passaria a receber no imaginário social e acadêmico uma espécie de não-lugar: a república que o povo não viu; se viu, não entendeu; quando entendeu, não quis. Como se ela tivesse descido do céu como um raio e se instaurado abruptamente no país, em um país despreparado para ela, em um país que não tinha condição alguma para recebê-la. Como se ela não fosse, ao contrário, fruto de tensões, amadurecimentos e aprendizagens que estavam em curso nesse mesmo país pelo menos desde a declaração da Independência.

É sintomática, nesse sentido, a maneira como Christian Lynch e Heloisa Starling escolhem terminar seu verbete sobre o conceito de república no projeto Iberconceptos:

De fato, a última rebelião do Império, a Revolta da Praieira, ocorrida em 1848 no Recife, não manifestaria pretensões republicanas nem separatistas, e ainda quarenta anos depois, numa carta íntima, um general sintetizaria de forma lapidar suas expectativas em torno da forma de governo republicana: 'República, no Brasil, e desgraça completa é a mesma coisa.' (LYNCH; STARLING, 2009, p. 241)

Narrativas como essa são ainda hoje hegemônicas no Brasil. Como regra, elas trazem consigo alguma perspectiva teórico-social. Na maioria das vezes, essa perspectiva aparece de modo subjacente, sem que haja qualquer explicitação e problematização da mesma no corpo do texto. Daí a relevância deste último tópico destinado à relação entre história e teoria social.

\footnotetext{
${ }^{25}$ Sobre o debate, cf. CARVALHO NETTO, 1992, p. 59-85; REPOLÊS, 2008, p. 35-66.

${ }^{26}$ Cf. nota 11 acima. É interessante notar que, apesar da relevância do conceito de soberania, como se procurou mostrar neste tópico e no tópico precedente, tal conceito não se encontra presente no primeiro tomo do Diccionario Político y Social del Mundo Ibero-Americano, cujos verbetes são: América/Americanos, Cidadão/Vizinho, Constituição, Federação/Federalismo, História, Liberal/Liberalismo, Nação, Opinião Pública, Povo/Povos e República/Republicano. É apenas no segundo tomo que o conceito de soberania ganha seu lugar, ao lado dos seguintes verbetes: Civilização, Democracia, Estado, Independência, Liberdade, Ordem, Partido, Pátria e Revolução. Infelizmente, não pude consultar o verbete referente à soberania para a redação deste texto. Por outro lado, fazendo justiça uma vez mais ao excelente trabalho de Lúcia das Neves, o conceito de soberania é especificamente por ela abordado nas páginas 159 a 162 de sua tese. (NEVES, 2003, p. 159-162). A centralidade do conceito de soberania é também reconhecida na introdução geral à coletânea em que recentemente foram publicados os panfletos da Independência brasileira. Essa introdução, bem como a organização da coletânea como um todo, é de responsabilidade de Lúcia das Neves, José Murilo de Carvalho e Marcello Basile. Cf. CARVALHO; BASTOS; BASILE, 2014, especificamente v. 1, p. 35.
} 
O objetivo precípuo aqui é, nestes poucos parágrafos voltados ao tema, enfatizar a inadequação da visada teórico-social que acompanha tais narrativas hegemônicas, inadequação que se revela em sua incapacidade de compreender toda a complexidade dos processos que possibilitaram a formação da república entre nós. A ausência de rupturas marcantes em nossa história, com eventos e marcos bem definidos, acompanhada pela permanência histórica de práticas de corrupção no interior do aparato estatal, pelo enclausuramento da esfera política e por índices significativos de normas jurídicas sem efetividade imediata são argumentos geralmente utilizados para sustentar a tese da república inconclusa, da república inacabada, da república impossível, ou qualquer coisa semelhante. Esses argumentos, porém, apoiam-se em uma visada teórico-social meramente descritiva, isto é, que se contenta em reunir os dados que vêm à superfície. O problema é que mudanças profundas em termos de estruturas e dinâmicas sociais não dependem necessariamente de dados que se dão a ver com clareza na superfície. No caso específico do Brasil e da história da república no Brasil durante o século XIX, mesmo que a camada mais externa da história, ou seja, aquilo que se mostra imediatamente ao olhar do observador, não contenha elementos suficientes para permitir que uma teoria social descritiva enxergue os processos de mudanças e aprendizagem republicanas em curso, isso não significa que esses processos não estivessem a ocorrer. Significa apenas que a perspectiva teórico-social utilizada não é adequada para abrangê-los.

Diante disso, uma alternativa que desponta é o abandono dessa perspectiva, descritiva, em prol de uma teoria social reconstrutiva, nos moldes propostos por Jūrgen Habermas. Uma teoria social reconstrutiva pode ser compreendida como tendo também por interesse, ao lado de uma descrição elaborada do ponto de vista de um observador externo, a compreensão do sentido que os próprios atores internamente atribuem às ações das quais participam, buscando, assim, reconstruir esse sentido imanente como antecipação contrafática. Em outras palavras, ainda que os fatos revelem, durante o período imperial brasileiro, certa continuidade na configuração da sociedade e da política, certo enclausuramento da classe política em si mesma, atos reiterados de confusão entre o público e o privado e baixa efetividade das normas jurídicas postas, ao mesmo tempo, contrafaticamente é possível vislumbrar um conjunto de práticas cujo sentido interno articulado por seus agentes apontava para a crítica a essa, e para a superação dessa, ordem de coisas, em direção a um arranjo republicano. Na linguagem do próprio Habermas, isso significa buscar na história fragmentos de racionalidade já presentes e que podem ser reconstruídos em uma abordagem teórica adequada (HABERMAS, 1998, p. 363-364).

Inevitavelmente, a perspectiva teórico-social que acompanha as leituras hegemônicas da história da república no Brasil27 conduz à conclusão de que a república nasceu prematura entre nós, de que ela nasceu antes

\footnotetext{
${ }^{27} \mathrm{Na}$ verdade, não é exagero dizer que essa perspectiva acompanha as leituras hegemônicas da história do Brasil como um todo. Nesse sentido, a expressão "leituras hegemônicas" teria como pressuposto lógico a possibilidade de identificar certo pano de fundo compartilhado por toda uma gama de autores centrais para a tradição teórica geralmente identificada como "intérpretes do Brasil" ou "pensamento social brasileiro", indo desde Francisco de Adolfo Varnhagen até nomes como Raymundo Faoro, Fernando
} 
de poder nascer e, por não ter consequentemente encontrado condições sociais propícias a seu florescimento, jamais se fortaleceu, jamais se consolidou. Como não houve grandes rupturas, como o império pouco se diferenciou da colônia no que tange às práticas da política e à estrutura e à dinâmica sociais, a república apareceu de modo abrupto, da noite para o dia, em um golpe de madrugada, frente a um povo que a tudo assistia bestializado. Ao contrário, a conclusão inelutável que deriva de uma perspectiva teórico-social reconstrutiva é o abandono do dogma dos bestializados: a história da república entre nós é a história do processo de amadurecimento e aprendizagem social acerca dos sentidos da república, amadurecimento e aprendizagem esses que têm curso, ainda que contrafaticamente, pelo menos desde a Independência.

Sem dúvida, a proclamação da república dependeu de uma conjuntura na qual confluíram diversos fatores. Alguns deles mais próximos, outros mais distantes, dos anseios republicanos que imanentemente já se faziam presentes na tessitura política e social brasileira. Mas mesmo tal conjuntura, em que fatores alheios ao ideal republicano convergiam para um desfecho em forma de república, não seria possível se aqueles anseios não possuíssem desde antes força vinculante suficientemente arraigada: a defesa da república não era em absoluto o único caminho de crítica possível ao império; a inelutabilidade desse caminho dependia, pois, da própria força atrativa que a república já conseguira alcançar.

No presente texto, essas conclusões que agora se revelam como advindas de um ponto de vista teóricosocial reconstrutivo foram sustentadas por meio da história do conceito de república, que não se perfaz sem a história correlata do conceito de soberania. Para tanto, a História dos Conceitos koselleckiana e o Enfoque Collingwoodiano de Pocock e Skinner continuam sendo as melhores ferramentas metodológicas. Outras pesquisas, com outras metodologias, poderiam vir a corroborar a argumentação aqui desenvolvida. Qualquer que seja o caso, independentemente do objeto da pesquisa ou da metodologia adotada, é indispensável uma reflexão teórico-social de fundo, sem a qual, por mais inovadores que sejam os objetos, por mais sofisticadas que sejam as metodologias, as conclusões podem não conseguir ser mais do que elos a prolongar a extensa cadeia de um

Henrique Cardoso e José Murilo de Carvalho, bem como passando por clássicos como Sérgio Buarque de Holanda e Caio Prado Júnior. Ou seja, como se pode notar, seria de tal monta a força desse pano de fundo que ele se faria presente mesmo em autores cujas perspectivas de interpretação do Brasil diferem umas das outras em pontos cruciais. No campo especificamente jurídico, essa tradição, com o pano de fundo que a acompanha, demonstra essa mesma força, por exemplo, na compreensão ainda hoje dominante acerca da história constitucional brasileira: esta seria supostamente captada de modo mais adequado por expressões conceituais como "crise constituinte" (BONAVIDES, 2008, p. 18), "constitucionalismo ornamental" (COMPARATO, 2007, p. 18-22), "constitucionalização simbólica" (NEVES, 2016), "constitucionalismo da inefetividade” (NETO; LYNCH, 2008, p. 25, nota de rodapé n. 2) e "Constituição puramente nominal” (STRECK, 2014), todas preocupadas, em que pesem as diferenças entre elas, em constatar, de maneira alegadamente crítica, o que seria a história de fracasso dos ideais republicanos e democráticoconstitucionais no Brasil. Não cabe no presente artigo um tratamento mais aprofundado das questões que certamente emergem a partir desta nota de rodapé. Mas, para uma discussão em termos gerais sobre a interpretação do Brasil, sugere-se a consulta a SOUZA, 2009 e a TAVOLARO, 2005. Para uma discussão mais específica sobre a história constitucional brasileira, por sua vez, a sugestão é CATTONI DE OLIVEIRA, 201 la; 2016. Finalmente, minha posição acerca desses temas - em boa medida, ainda em 
imaginário ressentido e derrotista, cujo mantra parece ser: "Toda história é remorso" (DRUMMOND DE ANDRADE, 1955, p. 386). ${ }^{28}$

Romper com esse imaginário é a tarefa mais urgente - e, por isso mesmo, a mais difícil - de qualquer estudo historiográfico que se pretenda crítico no Brasil de hoje.

\title{
ABOUT THE REPUBLIC DURING THE EMPIRE: BETWEEN HISTORY AND SOCIAL THEORY
}

\begin{abstract}
This paper approaches the history of the concepts of republic and sovereignty in nineteenth-century Brazil. The aim is to demonstrate that understanding the concept of republic is not possible without understanding its internal relations with the concept of sovereignty, but at the same time this understanding demands a background that can be offered only by a reflection coming from the social theory. At first, it discusses the concept of republic between 1750 and 1850 as presented in the Iberconceptos project. Next, it focuses on Frei Caneca's writings to analyse the concept of republic in the context of Brazil's Independence and to relate it to the concept of sovereignty. Afterwards, it demonstrates the overall articulation between the concepts of republic and sovereignty from Brazil's Independence to the Republican Party's Manifest. Finally, it presents a reflection about the relationship between history and social theory.
\end{abstract}

Keywords: Republic; Sovereignty; 19th Century's Brazil; Social Theory.

\section{REFERENNCIAS BIBLIOGRÁFICAS}

\section{Fontes primárias}

ANDRADA E SILVA, José Bonifácio de. José Bonifácio de Andrada e Silva. Org. e int. Jorge Caldeira. São Paulo: Ed. 34, 2002.

BRASIL. Diário da Assembléia Geral Constituinte e Legislativa do Império do Brasil de 1823 (1823). Brasília: Senado Federal, 1973.

Constituicão Politica do Imperio do Brazil (1824). Disponível em: <http://www.planalto.gov.br/ccivil_03/constituicao/constituicao24.htm>. Acesso em:31/07/2015.

tom ensaísta - pode ser encontrada com mais detalhes em: GOMES; CATTONI DE OLIVEIRA, 2012; GOMES, 2015; GOMES, 2016.

${ }^{28}$ Nesse sentido, cabe destacar a linha de pesquisa que Marcelo Andrade Cattoni de Oliveira vem coordenando no Programa de Pós-Graduação em Direito da UFMG. Tal linha leva a sério exatamente a preocupaçãocom uma aproximação, metodologicamente bem concertada, entre a filosofia, a história e a teoria social, além, claro, do direito. Para o programa geral da pesquisa coordenada por Marcelo Andrade Cattoni de Oliveira, cf. CATTONI DE OLIVEIRA, 201 la. Para uma reflexão mais detida na relação desse projeto com a teoria social crítica frankfurtiana, cf. CATTONI DE OLIVEIRA, 2015. 
CANECA, Frei Joaquim do Amor Divino. Dissertação sobre o que se deve entender por pátria do cidadão e deveres deste para com a mesma pátria (1822). In: CANECA, Frei Joaquim do Amor Divino. Frei Joaquim do Amor Divino Caneca. Org. e int. Evaldo Cabral de Mello. Coleção Formadores do Brasil. São Paulo: Ed. 34, 2001a, p. 53-99.

Sermão da aclamação de D. Pedro I. In: CANECA, Frei Joaquim do Amor Divino (1822). Frei Joaquim do Amor Divino Caneca. Org. e int. Evaldo Cabral de Mello. Coleção Formadores do Brasil. São Paulo: Ed. 34, 2001b, p. 101-119.

Resposta às calúnias e falsidades da Arara Pernambucana, redigida por José Fernandes Gama, preso na corte do Rio de Janeiro. (1823). In: CANECA, Frei Joaquim do Amor Divino. Frei Joaquim do Amor Divino Caneca. Org. e int. Evaldo Cabral de Mello. Coleção Formadores do Brasil. São Paulo: Ed. 34, 2001c, p. 123-134.

$\mathrm{O}$ Caçador atirando à Arara Pernambucana em que se transformou o rei dos ratos José Fernandes Gama (1823). In: CANECA, Frei Joaquim do Amor Divino. Frei Joaquim do Amor Divino Caneca. Org. e int. Evaldo Cabral de Mello. Coleção Formadores do Brasil. São Paulo: Ed. 34, 2001d, p. 135-163.

Cartas de Pítia a Damão (1823). In: CANECA, Frei Joaquim do Amor Divino. Frei Joaquim do Amor Divino Caneca. Org. e int. Evaldo Cabral de Mello. Coleção Formadores do Brasil. São Paulo: Ed. 34, 2001e, p. 165-300.

O Typhis Pernambucano (1823-1824). In: CANECA, Frei Joaquim do Amor Divino. Frei Joaquim do Amor Divino Caneca. Org. e int. Evaldo Cabral de Mello. Coleção Formadores do Brasil. São Paulo: Ed. 34, 2001f, p. 301-533.

Voto sobre o reconhecimento de Francisco Paes Barreto como presidente da província de Pernambuco (1824). In: CANECA, Frei Joaquim do Amor Divino. Frei Joaquim do Amor Divino Caneca. Org. e int. Evaldo Cabral de Mello. Coleção Formadores do Brasil. São Paulo: Ed. 34, 2001g, p. 535-543.

Voto sobre o juramento do projeto de Constituição oferecido por d. Pedro I (1824). In: CANECA, Frei Joaquim do Amor Divino. Frei Joaquim do Amor Divino Caneca. Org. e int. Evaldo Cabral de Mello. Coleção Formadores do Brasil. São Paulo: Ed. 34, 2001h, p. 557-566.

Itinerário que fez frei Joaquim do Amor Divino Caneca, saindo de Pernambuco a 16 de setembro de 1824, para a província do Ceará Grande (1824). In: CANECA, Frei Joaquim do Amor Divino. Frei Joaquim do Amor Divino Caneca. Org. e int. Evaldo Cabral de Mello. Coleção Formadores do Brasil. São Paulo: Ed. 34, 2001i, p. 567-605.

Processo de frei Joaquim do Amor Divino Caneca, em 1824 (1824). In: CANECA, Frei Joaquim do Amor Divino. Frei Joaquim do Amor Divino Caneca. Org. e int. Evaldo Cabral de Mello. Coleção Formadores do Brasil. São Paulo: Ed. 34, 2001j, p. 607-643.

Decreto de 12 de novembro de 1823 (1823). In: BONAVIDES, Paulo; ANDRADE, Paes de. História constitucional do Brasil. 9a. ed. Brasília: OAB, 2008a, p. 557.

Decreto de 13 de novembro de 1823 (1823). In: BONAVIDES, Paulo; ANDRADE, Paes de. História constitucional do Brasil. 9a. ed. Brasília: OAB, 2008b, p. 559.

Manifesto do Príncipe Regente aos brasileiros sobre os conflitos com Portugal e a expectativa de independência (1822). In: BONAVIDES, Paulo; AMARAL, Roberto. Textos Políticos da História do Brasil. 3a. ed. v. 1. Brasília: Senado Federal, 2002, p. 619-626.

Manifesto de D. Pedro I justificando a dissolução da Constituinte (1823). In: BONAVIDES, Paulo; AMARAL, Roberto. Textos Políticos da História do Brasil. 3a. ed. v. 1. Brasília: Senado Federal, 2002, p. 558.

Manifesto Republicano aos Nossos Concidadãos (1870). In: CHACON, Vamireh. História dos partidos brasileiros - discurso e práxis dos seus programas. 3a. ed. amp. e atual. Brasília: Editora UnB, 1998, p. 243-260. 
Proclamação do Imperador D. Pedro I justificando a convocação de uma nova Assembléia Constituinte (1823). In: BONAVIDES, Paulo; AMARAL, Roberto. Textos Políticos da História do Brasil. 3a. ed. v. 1. Brasília: Senado Federal, 2002, p. 741-742.

\section{Bibliografia}

ARAÚJO, Valdei Lopes. A experiência do tempo: conceitos e narrativas na formação nacional brasileira (18131845). São Paulo: Aderaldo e Rothschild, 2008.

BONAVIDES, Paulo. A Constituição do Império e as nascentes do constitucionalismo brasileiro. In: ROCHA, Cléa Carpi et al. (orgs.). As constituições brasileiras: notícia, história e análise crítica. Brasília: OAB Editora, 2008, p. 13-24.

BONAVIDES, Paulo; ANDRADE, Paes de. História constitucional do Brasil.9a. ed. Brasília: OAB, 2008.

CANCELLI, Elizabeth. Perspectivas historiográficas brasileiras e suas rupturas com os "males do passado". História: Questões \& Debates, Editora UFPR, Curitiba, n. 50, jan./jun. 2009, p. 51-59.

CARVALHO, José Murilo de. Apresentação. In: GRINBERG, Keila; SALLES, Ricardo (orgs). O Brasil Imperial, v. I: 1808-1831. Rio de Janeiro: Civilização Brasileira, 2009, p. 7-10.

Nação e cidadania no Império: novos horizontes. Rio de Janeiro: Civilização Brasileira, 2007.

CARVALHO, José Murilo de; NEVES, Lúcia Maria Bastos Pereira da (orgs.). Repensando o Brasil do Oitocentos: cidadania, política e liberdade. Rio de Janeiro: Civilização Brasileira, 2009.

CARVALHO, José Murilo; BASTOS, Lúcia; BASILE, Marcello (orgs.). Guerra Literária: panfletos da Independência (1820-1823). 4 v. Belo Horizonte: UFMG, 2014.

CARVALHO NETTO, Menelick de. A sanção no procedimento legislativo. Belo Horizonte: Del Rey, 1992.

CATTONI DE OLIVEIRA, Marcelo Andrade. Notas programáticas para uma nova história do processo de constitucionalização brasileiro. In: CATTONI DE OLIVEIRA, Marcelo Andrade (coord.). Constitucionalismo e História do Direito. Belo Horizonte: Pergamum, 201 1a, p. $19-59$.

Democracia sem espera e processo de constitucionalização: uma crítica aos discursos oficiais sobre a chamada "transição política brasileira". In: CATTONI DE OLIVEIRA, Marcelo Andrade (coord.). Constitucionalismo e História do Direito. Belo Horizonte: Pergamum, 201 lb, p. 207-247.

Teoria Tradicional e Teoria Crítica da Constituição: Notas programáticas para uma nova história e teoria do processo de constitucionalização brasileiro. Disponível em: <http://www.academia.edu/12977582/Teoria_Tradicional_e_Teoria_Cr\%C3\%ADtica_da_Constitui\%C3\% A7\%C3\%A3o_Notas_program\%C3\%Alticas_para_uma_nova_hist\%C3\%B3ria_e_teoria_do_processo_de _constitucionaliza\%C3\%A7\%C3\%A3o_brasileiro>. Acesso em: 10/08/2015.

Contribuições para uma nova história e teoria do processo de constitucionalização brasileiro no marco $\mathrm{da}$ teoria crítica da constituição. Belo Horizonte, 2015. Disponível em: <https://www.academia.edu/21327760/Projeto_de_Pesquisa_CNPq_Contribui\%C3\%A7\%C3\%B5es_para _uma_Nova_Hist\%C3\%B3ria_e_Teoria_do_Processo_de_Constitucionaliza\%C3\%A7\%C3\%A3o_Brasileir o_no_Marco_da_Teoria_Cr\%C3\%ADtica_da_Constitui\%C3\%A7\%C3\%A3o >. Acesso em: 14/07/2016. 
CATTONI DE OLIVEIRA, Marcelo Andrade; GOMES, David F. L. Independência ou sorte?: ensaio de história constitucional do Brasil. Revista da Faculdade de Direito (UFPR), v. 55, p. 19-37, 2012.

COMPARATO, Fábio Konder. Prefácio. In: FAORO, Raymundo. A República inacabada. Org. Fábio Konder Comparato. São Paulo: Globo, 2007, p. 7-24.

DANTAS, Mônica Duarte. Revoltas, motins, revoluções: homens livres pobres e libertos no Brasil do século XIX. São Paulo: Alameda, 2011.

DRUMMOND DE ANDRADE, Carlos. Claro Enigma. In: DRUMMOND DE ANDRADE, Carlos. Fazendeiro do Ar e Poesia Até Agora. Rio de Janeiro: José Olympio, 1955, p. 339-423.

FERES JÚNIOR, João (org.). Léxico da história dos conceitos políticos do Brasil. Belo Horizonte: Editora UFMG, 2009a.

Reflexões sobre o Projeto Iberconceptos. In: FERES JÚNIOR, João (org.). Léxico da história dos conceitos políticos do Brasil. Belo Horizonte: Editora UFMG, 2009b, p. 11-24.

FERES JÚNIOR, João; JASMIN, Marcelo Gantus (org.). História dos Conceitos: debates e perspectivas. Rio de Janeiro: PUC-Rio/Loyola/IUPERJ, 2006.

FERREIRA FILHO, Manoel Gonçalves. A democracia possível. 5a. ed., rev. São Paulo: Saraiva, 1979.

GOMES, David F. L. Razões para uma Ditadura: Manoel Gonçalves Ferreira Filho e a Democracia Possível. Revista do CAAP, v. 2, 2010, p. 49-66.

"Houve mão mais poderosa"?: Soberania e Modernidade na Independência do Brasil. Belo Horizonte: Initia Via, 2015.

A Constituição de 1824 e O Problema da Modernidade: O Conceito Moderno de Constituição, A História Constitucional Brasileira e A Teoria da Constituição no Brasil. Tese (doutorado). Belo Horizonte: UFMG, 2016.

GOMES, David F. L.; CATTONI DE OLIVEIRA, Marcelo Andrade. Independência ou sorte?: ensaio de história constitucional do Brasil. Revista da Faculdade de Direito (UFPR), v. 55, 2012, p. 19-37.

GRINBERG, Keila; SALLES, Ricardo (orgs). O Brasil Imperial.3v. Rio de Janeiro: Civilização Brasileira, 2009.

HABERMAS, Jürgen. Facticidad y Validez: Sobre el Derecho y el Estado de Derecho en términos de Teoría del Discurso. Trad. Manuel Jiménez Redondo. Madrid: Trotta, 1998.

HAMILTON, Alexander; MADISON, James; JAY, John. The federalist papers. New York: Mentor Book, 1961.

JANCSÓ, István (org.). Brasil: Formação do Estado e da Nação. São Paulo: Hucitec; Unijuí; Fapesp, 2003.

Independência: história e historiografia. São Paulo: Hucitec, 2005.

KOSELLECK, Reinhart. Futuro passado: contribuição à semântica dos tempos históricos. Rio de Janeiro: Contraponto/PUC-RJ, 2006.

KOSELLECK, Reinhart; GADAMER, Hans-Georg. Histórica y Hermenêutica. Trad. Faustino Oncina. Barcelona: Paidós, 1997. 
LE GOFF, Jacques. História Nova. 2a. ed. São Paulo: Martins Fontes, 1993.

LUSTOSA, Isabel. Insultos impressos: a guerra dos jornalistas na independência (1821-1823). São Paulo: Companhia das Letras, 2000.

Criação, Ação e Dissolução da Primeira Assembléia Constituinte Brasileira: 1823. In: LUSTOSA, Isabel. As trapaças da sorte: ensaios de história política e de história cultural. Belo Horizonte: Editora UFMG, 2004, p. 51-79.

LYNCH, Christian; STARLING, Heloisa. República/Republicanos. In: FERES JÚNIOR, João (org.). Léxico da história dos conceitos políticos do Brasil. Belo Horizonte: Editora UFMG, 2009, p. 225-245.

MALERBA, Jurandir (org.). A independência brasileira: novas dimensões. Rio de Janeiro: Editora FGV, 2006b, p. $19-52$.

MATTOS, Ilmar Rohloff de. O Tempo saquarema: a formação do Estado Imperial. 5a. ed. São Paulo: HUCITEC, 2004.

MELLO, Evaldo Cabral. Frei Caneca ou a outra Independência. In: CANECA, Frei Joaquim do Amor Divino. Frei Joaquim do Amor Divino Caneca. Org. e int. Evaldo Cabral de Mello. Coleção Formadores do Brasil. São Paulo: Ed. 34, 2001, p. 11-47.

MOREL, Marco. As transformações dos espaços públicos: imprensa, atores políticos e sociabilidades na Cidade Imperial (1820-1840). São Paulo: Hucitec, 2005.

NETO, Cláudio Pereira de Souza; LYNCH, Christian Edward Cyril. O constitucionalismo da inefetividade: a Constituição de 1891 no cativeiro do estado de sítio. In: ROCHA, Cléa Carpi et al. (orgs.). As constituições brasileiras: notícia, história e análise crítica. Brasília: OAB Editora, 2008, p. 25-60.

NEVES, Lúcia Maria Bastos Pereira das. Corcundas e constitucionais: a cultura e política da independência (1820-1822). Rio de Janeiro: Revan.: FAPERJ, 2003.

NEVES, Marcelo. A constitucionalização simbólica. 3a. ed., 3a. tir. São Paulo: WMF Martins Fontes, 2016.

PALTI, Elias José. O século XIX brasileiro, a nova história política e os esquemas teleológicos. In: CARVALHO, José Murilo; NEVES, Lúcia Maria Bastos Pereira da (orgs.). Repensando o Brasil do Oitocentos: cidadania, política e liberdade. Rio de Janeiro: Civilização Brasileira, 2009, p. 581-597.

PEREIRA, Vantuil. Ao Soberano Congresso: Direitos do cidadão na formação do Estado Imperial brasileiro (1822-1831). São Paulo: Alameda, 2010.

POCOCK, John G. A. Linguagens do ideário político. São Paulo: EDUSP, 2003.

REPOLÊS, Maria Fernanda Salcedo. Quem deve ser o guardião da Constituição? Do Poder Moderador ao Supremo Tribunal Federal. Belo Horizonte: Mandamentos, 2008.

RICOEUR, Paul. La mémoire, l'histoire, l'oubli. Paris: Éd. du Seuil, 2000.

SEBASTIÁN, Javier Fernández (dir.). Diccionario político y social del mundo iberoamericano. T. I. Madrid: 
Centro de Estudios Políticos y Constitucionales - Universidad del País Vasco, 2009.

Diccionario político y social del mundo iberoamericano. T. II. Madrid: Centro de Estudios Políticos y Constitucionales - Universidad del País Vasco, 2014.

SKINNER, Quentin. Los fundamentos del pensamiento político moderno. Trad. Juan José Utrilla. v. 1. México: Fondo de Cultura Económica, 1985.

Los fundamentos del pensamiento político moderno. Trad. Juan José Utrilla. v. 2. México: Fondo de Cultura Económica, 1986.

Visions of politics. v. 1. Cambridge; New York: Cambridge University Press, 2002.

SOUZA, Jessé et al.. A ralé brasileira: quem é e como vive. Belo Horizonte: Editora UFMG, 2009.

Os batalhadores brasileiros: nova classe média ou nova classe trabalhadora? 2a. ed. rev. e ampl. Belo Horizonte: Editora UFMG, 2012.

STRECK, Lenio Luiz. Jurisdição constitucional e decisão jurídica. 4a. ed. São Paulo: Revista dos Tribunais, 2014.

TAVOLARO, Sergio B. F. Existe uma modernidade brasileira? Reflexões em torno de um dilema sociológico brasileiro. RBCS, v. 20, n. 59, out. 2005, p. 5-22.

Trabalho enviado em 23 de agosto de 2016. Aceito em 03 de março de 2017. 